(C) 1989 ISIJ

IIIIIIIIIIIIIIIIII

論 文

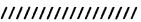

\section{チタン酸カリウムウィスカーによる \\ 6061 合金の強化}

菅沼克昭 $*$ ·藤田輝昭 $*$ 新原皓一 $* 2 \cdot$ 鈴木信幸 $* 3$

\title{
Reinforcement of 6061 Alloy with Potassium Titanate Whisker
}

Katsuaki Suganuma, Teruaki Fujita, Koichi Niıhara and Nobuyuki SuzukI

\begin{abstract}
Synopsis :
Feasibility of potassium titanate whisker as the reinforcement of 6061 aluminum alloy was examined. The volume fraction of whisker was $20 \%$ and the squeeze casting method was adopted. Tensile test, measurements of Young's modulus and thermal expansion coefficient were performed. Reaction at the whisker/matrix interface was observed by analytical and high resolution transmission electron microscopy.

The strength of the extruded composite reached $410 \mathrm{MPa}$, which is quite good. TEM obsevation revealed that no severe reaction occurred between the whisker and the matrix though magunesium segregated at the interface. Thus, the potassium titanate whisker is very much stable in the 6061 matrix and it has a good potential as the reinforcement of aliminum alloys because of its low cost.

Key words : potassium titanate whisker; whisker reinforcement ; hot extrusion ; interface ; HREM ; 6061 alloy ; FRM ; tensile strength.
\end{abstract}

1. 緒

セラミック織維で強化されたアルミニウム合金複合材 料は，その優れた性質である中高温域までの高強度，高 弾性, 耐疲労特性, 低熱膨張, あるいは耐摩耗性等から, 早い時期から多方面での使用が期待されてきている。し かし，実際には航空機などの非常に限られた分野でのみ 実用化されているが，一般の広い分野，特に期待の最も 大きい自動車産業での実用化は極めて少ないのが現状で ある.この複合材料の幅広い実用化を阻んでいる原因に はいくつかの事柄が挙げられるが，中でも優れた特性を 損なうことなく一般工業材料に適用可能な程度に安価な 複合材料を製造するプロセスが未確立であることが大き な要因として考えられる. 複合材料が現存の工業材料に 置き替わるためには，いうまでもなく信頼性は高くある べきであるが，現在のように製造コストが高いままであ るとその利用範囲は宇宙航空産業のような特殊な分野に 限られてしまう。複合材料の製造コストを左右する最も 大切な因子としては, セラミック繊維自身のコストと複 合化プロセスのコストの両方を考慮する必要がある．本
研究で強化織維として取り上げたチタン酸カリウムウィ スカーは, セラミック䄉維の中では格別に安価であり(研 究の盛んに行われている炭化珪素䄉維の数十分の一, 実 用化されているアルミナ短繊維の約四〜五分の一)，ま た製造プロセスとして取り上げた高圧鋳造法は, 量産化 が可能な数少ないプロセスの一つである. したがって, もし両者の組合せで優れた複合材料の製造が達成できれ ば，金属基複合材料の実用化に格段の進歩が得られると 期待できる。

チタン酸カリウムウィスカーとアルミニウムとの反応 性に関しては, 福永ら ${ }^{1)}$ が純アルミニウム粉末とウィス カーとを混合した後, 高温保持し, EPMAにより調べ ている，その結果，高圧鋳造に要求される温度範囲であ る $973 \mathrm{~K}$ 以上の温度で, カリウムの溶出が起こること が分かっている．また，最近の報告2)では，粉末治金法 ではこれより低温で複合ができるので, 反応の問題は避 けられることが分かっている. しかし，粉末治金法はプ ロセスとして高価になるため,この織維の安価であると いう他の繊維に比較しての優位性を十分に活かしきれな い.また，高圧鋳造法でも温度制御を十分に行うことに

昭和 63 年 12 月 8 日受付 (Received Dec. 8, 1988)

* 防衛大学校応用物理学教室（現：防衛大学校材料物性工学教室） 工博 (Department of Applied Physics, Now Department of Material Science, The National Defense Academy, 1-10-20 Hashirimizu Yokosuka 239)

*2 大阪大学産業科学研究所 (The Institute of Scientific and Industrial Research, Osaka University)

*3 エー・エム・テクノロジー (Advanced Material Technologies Co. Ltd.) 
より純アルミニウムとの複合材の製造が可能なことが示 ざれたが，6061 合金をマトリックスとする場合では T6 処理により強度劣化することが報告されている3).この ように過去の例では, チタン酸カリウムウィスカーはア ルミニウム合金との高圧鋳造法による複合化は困難であ ると考えられてきた。しかし，最近になってチタン酸力 リウムウィスカー自身が改良されており，アルミニウム 合金との反応性及び複合性を再度検討する必要が生じて きた，本研究ではこの背景を受けて，改良型の六チタン 酸カリウムウィスカーのアルミニウム合金との適合性を 調べることを目的に，6061 合金をマトリックスのモデ ル材料として選び,これらを高圧鋳造法により複合化し， 得られた複合材料の物理的性質及びウィスカー/マト リックス界面反応について調べた。

\section{2. 実 験 方 法}

チタン酸カリウムウィスカーは, チタン工業製 $\mathrm{HT}-300\left(\mathrm{~K}_{2} \mathrm{O} \cdot 6 \mathrm{TiO}_{2}\right)$ を用いた. X線回折より,このウィ スカーがほぼ単斜晶系のトンネル構造を持つ六チタン酸 カリウムであることが確認された. Photo. 1 にこのウィ スカーの SEM 像を示す. 繊維長は $10 \sim 100 \mu \mathrm{m}$, 繊維 径は $0.4 \sim 1.5 \mu \mathrm{m}$ の範囲にある. 6061 合金は市販のも のを用いた。

プリフォームは, ウィスカーの複合材料中の体積率が $20 \%$ になるようにシリカゾルを微量混合後 $773 \mathrm{~K}$ で焼 成し, $50 \mathrm{~mm} \phi \times 50 \mathrm{~mm}$ の寸法に作成した。高圧鋳造は, プリフォーム, 合金溶湯, 金型の温度をおのおの 1073 $\mathrm{K}, 1073 \mathrm{~K}, 523 \mathrm{~K}$ とし, 加圧力 $230 \mathrm{MPa}$ の条件で行っ

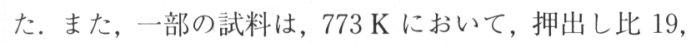
速度 $1.2 \mathrm{~mm} / \mathrm{min}$ の熱間押出しを施した。押出しに関す る実験方法は，筆者らの一部が遂行した以前の報告に詳



Photo. 1. SEM photograph of potassium titanate whisker.
しく示してある ${ }^{4)}$.

組織観察は, 高圧鋳造状態の複合材 (以下 $\mathrm{As}^{-}$cast 材と称する) とこれに T6 処理 $(793 \mathrm{~K}, 30 \mathrm{~min}$ 溶体化 後水中焼入れ, 続いて $348 \mathrm{~K} て ゙ 8 \mathrm{~h}$ の時効）を施した もの（以下 $\mathrm{T} 6$ 処理材と称する）に関し, EPMAによ る元素分析, STEM モードにおけるEDX 分析及び高 分解能電顕観察を行った. 電子顕微鏡 (以下 TEM と称 する) は JEOL200CX である。TEM 観察用試片は, $100 \mu \mathrm{m}$ 程度の厚さに切り出した試料を電解研磨により $10 \mu \mathrm{m}$ 程度に薄くし, 更にアルゴンイオンシンニングに より仕上げ作製した。

押出し材の物理的性質として, 引張強さ, ヤング率及 び熱膨張率を測定した。強度測定は, 平行部が $4 \mathrm{~mm} \times$ $1.5 \mathrm{~mm}$ の断面形状を持つ引張試験片を押出し材より切 り出し, T6 処理を施して室温で行った. 歪み速度は $1.3 \times 10^{-4} / \mathrm{s}$ である. ヤング率の測定は, 押出し材より $1 \mathrm{~mm} \times 5 \mathrm{~mm} \times 40 \mathrm{~mm}$ の板状の試験片を切り出し, T6 処 理を施し横振動法により室温において行った。更に，熱 澎張率の測定を, 押出し材より $5 \mathrm{~mm} \phi \times 15 \mathrm{~mm}$ の円柱 試片を切り出し, 押し棒方式（真空理工社製, DL-7000RHS）により室温から $573 \mathrm{~K}$ の範囲で測定し た.これらの值は, いずれも押出し方向に関し測定をし た.

\section{3. 結果と考察}

\section{$3 \cdot 1$ 複合材のマクロ組織及び反応，偏析}

Photo. 2(a) 及び(b) にAs-cast 材及び押出し材中の ウィスカーの分布状態を示した. 写真では Deep etch し表面のアルミニウムを除去してウィスカーのみが見え るようにしている. Photo. 1 と比較すると, As-cast 材, 押出し材の順にウィスカーが短くなっていることが認め られる. 同様のことは, 他の緎維の場合でも高圧鋳造及 び押出し加工を経ることにより生じるものである。 しか し，アスペクト比に関してはアルミナ短緎維の場合が同 条件の押出し加工により約 7 程度になることと比較する と ${ }^{4)}$, 押出し材でもアスペクト比が大きなものが多数観 察され，より有効な繊維強化が期待できる.

Fig. 1 に EPMAにより求めた複合材とマトリックス 合金の境界面を通しての元素分布状態を示した.チタン 酸カリウムウィスカーとアルミニウム合金の複合化にお いてもっとも問題とされていたウィスカーからマトリッ クスへのカリウムのマクロスケールでの溶出はほとんど 認められない。また，チタンの拡散等も認められない. このようにウィスカー側からマトリックス側への元素の 移動は, マクロスケールにはほとんど生じていないこと 
が分かった。一方，合金側の元素に関しては，マグネシ ウムとシリコンが境界面近くで多くなり，複合材中のマ グネシウムの量がマトリックス合金側より明らかに多く なっていることが認められる。また，マグネシウムは複 合材中に深く入るに従い徐々に減少していくこのこと は，主として合金中のマグネシウムがチタン酸カリウム ウィスカーと何らかの反応を生じていることを示唆する ものと考えられる。ただし，Photo. 2(a)または（b）の
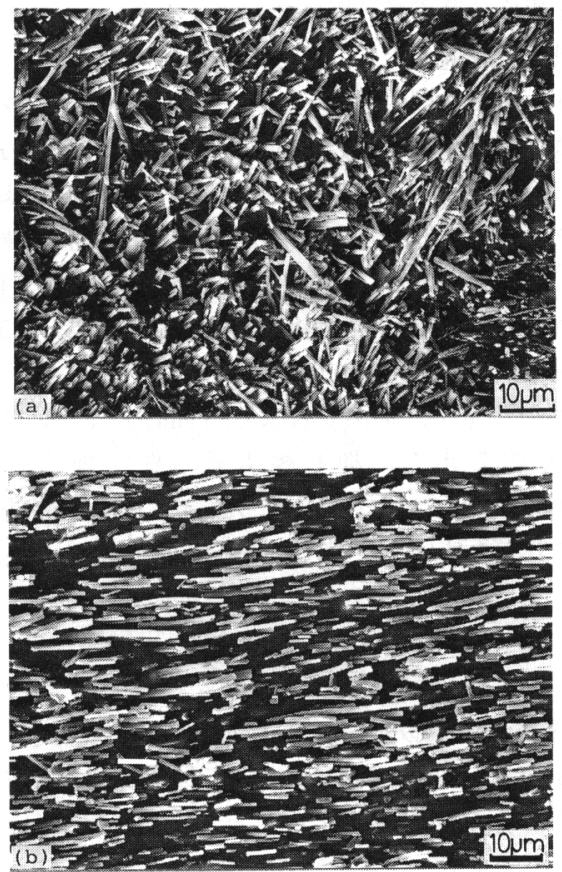

Photo. 2. SEM photographs of (a) the as-casted composite and (b) the hot-extruded composite. Matrix was deeply etched.

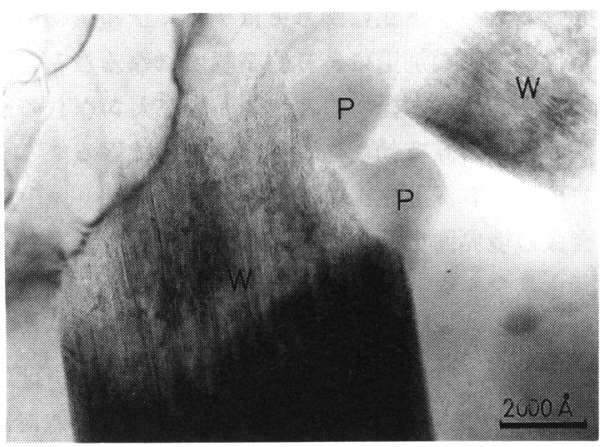

ウィスカー表面には, アルミナ㵶維等の場合に認められ るような $\mu \mathrm{m}$ オーダーの大きな析出物 ${ }^{4)}$ の形成はほとん ど認められず，反応が生じている場合でもそれは穏やか なものであると言える。

$3 \cdot 2$ 分析電顕及び高分解能電顕観察によるウィスカー /マトリックス界面組織

Photo. 3 にウィスカー表面に接してしばしば観察さ れた比較的大きな析出物の TEM 写真と EDX 分析結果 を示す.この析出物は, EDX 分析から分かるようにア

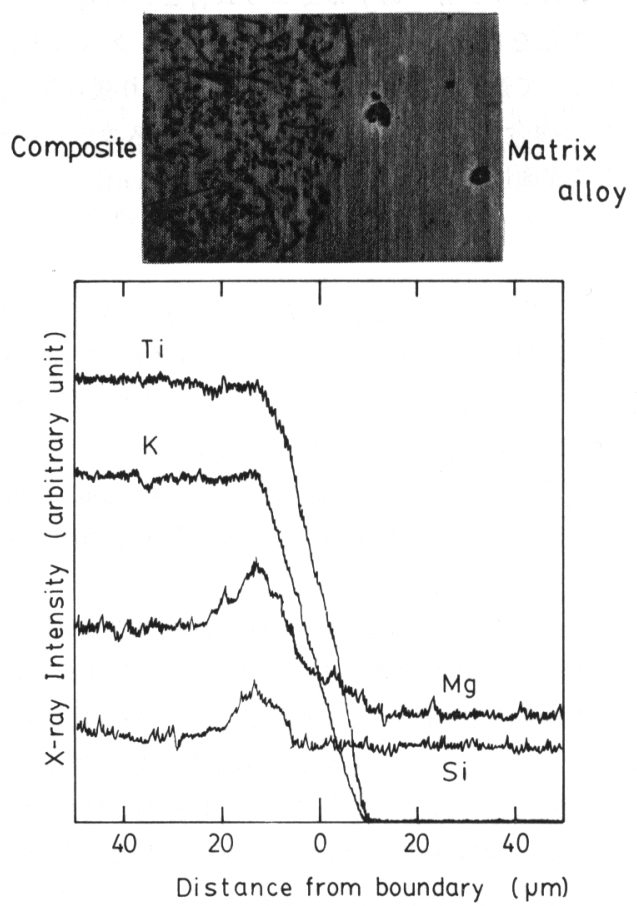

Fig. 1. EPMA line analyses across the bounbary between the composite and the matrix alloy.

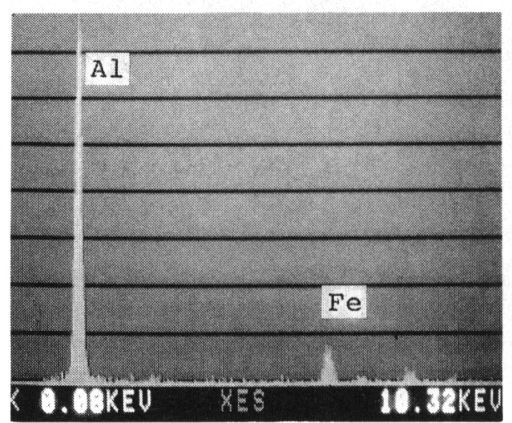

Photo. 3. TEM photograph of large precipitates on the whisker and their EDX profile. 
ルミニウムと鉄を主成分とする金属間化合物であり，繊 維とマトリックスの間の反応で生じたものではない。ま た，他のアルミニウム合金や FRM においてもしばしば 認められるものであり，アルミニウム合金に初めから含 まれる不純物元素 (主に鉄) による $\mathrm{Al}_{3} \mathrm{Fe}$ か $\mathrm{Al}-\mathrm{Fe}-\mathrm{Si}$ 系の金属間化合物と考えられる ${ }^{5)}$ 。この他には，界面上 にもマトリックス中にも大きな析出物は認められなかっ た。したがって，この範囲ではウィスカーとマトリック スの反応がある場合には，カリウムまたはチ夕ンは析出 物を形成するのではなくマトリックスに固溶していると 言える.

Photo. 4 及び 5 に As-cast 材及び $\mathrm{T} 6$ 処理材の TEM 写真とウィスカー/マトリックス界面近傍の EDX 分析結果を示した。分析場所は，界面より約 $200 \mathrm{~nm}$ の 距離のウィスカー内部の点, 界面上, 及び界面より約 $200 \mathrm{~nm}$ 離れたマトリックス内部の点の三か所である. マトリックス中にはカリウムあるいはチタンはほとんど 認められず，従ってその存在は EDX の分析分解能以下 (約 0.1 at \%) であると言える.また，界面上では，ウィ
スカーとマトリックスの両方の元素が認められるが, STEM モードの EDX 分析の空間分解能が約 $20 \mathrm{~nm}$ で あることを考虑すると，この結果は両方からの情報が重 なったものであると言える。ここで注目されることは， アルミニウムのピークの低エネルギー側に認められるマ グネシウムのピークが, マトリックス中のものよりわず かに高くなっていることである.これは，合金元素のマ グネシウムがウィスカーの周りに偏析していることを示 している。また，ウィスカーの周囲が数 $10 \mathrm{~nm}$ 幅でコ ントラストが濃くなっている。この低倍率観察の範囲で は，このコントラストが歪みのためか，あるいはマグネ シウムの偏析のために生じているのかは判断できない が，仮にこのコントラストが変化している層を反応生成 物層としても非常に薄いものであり, その場合の反応は 穏やかであると言える。これらの観察結果は，T6 処理 材に関してもまったく同様であった．以上のことから， ここで用いたチタン酸カリウムウイスカーは, マトリッ クスと本実験条件の高圧鋳造条件でマクロスケールには ほとんど反応せず，また $\mathrm{T} 6$ 処理によっても反応が進行


B

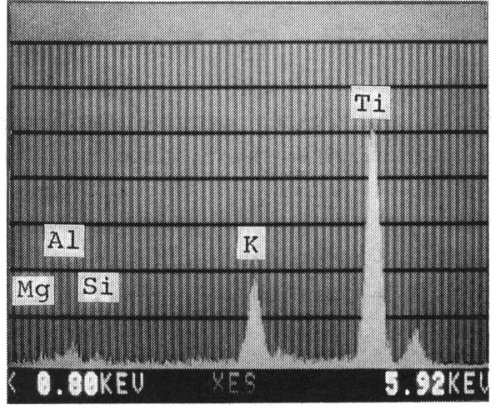

A

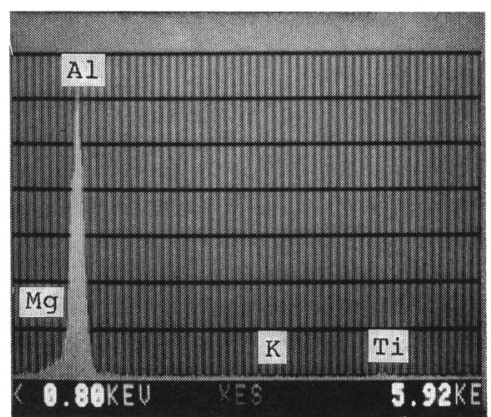

C

Photo. 4. TEM photograph of the as-cast composite and EDX profiles (A) in the whisker, (B) on the interface and $(\mathrm{C})$ in the matrix. "W" indicates whisker. 

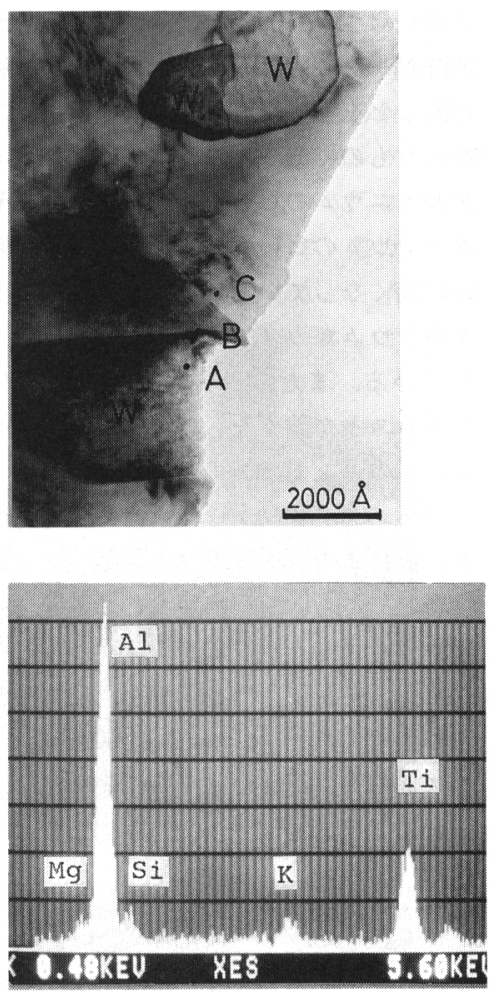

B



A

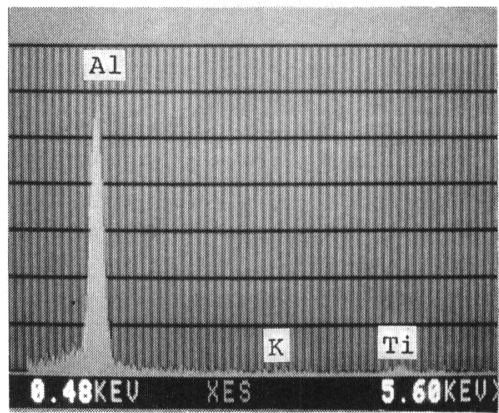

C

Photo. 5. TEM photograph of the T6 treated composite and EDX profiles (A) in the whisker, $(\mathrm{B})$ on the interface and $(\mathrm{C})$ in the matrix. "W" indicates whisker.

するものではないことが分かった。

Photo. 6 には T6 処理材におけるウィスカー/マト リックス界面の高倍率写真を示した。写真ではウィス カーは長さ方向を紙面に平行にしている. Photo. 4 及 び 5 でウィスカー周囲の濃いコントラスト部分がより 明確に観察される。しかし，その部分の輪郭は不鮮明で あり，一部ウィスカー内部には認められない新しい格子 縞が観察されるが, 円柱状ウィスカーの縦断面を観察し ているため界面が湾曲し， ウィスカーと濃いコントラス 卜部分が重なり，この格子縞が真にウィスカー表面の反 応生成物あるいは析出物によるものかどうかは判断でき ない. そこで, Photo. 7 にウィスカーを横断する界面 の高分解能写真を示した，写真には，ウィスカー中の幾 つかの格子とアルミニウムの $0.20 \mathrm{~nm}$ の面間隔を有す る格子の他に, 反応生成物（この粒子は $\mathrm{Mg}_{2} \mathrm{Si}$ 等の析 出物の可能性もあるが, ここでは以下に広い意味で反応 生成物と呼ぶ）からの $0.24 \mathrm{~nm}$ の面間隔の格子が認め られる。ウィスカー中の $0.64 \mathrm{~nm}$ の面は単斜晶

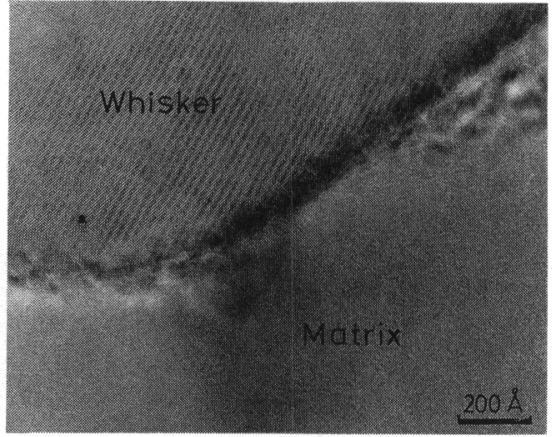

Photo. 6. TEM photograph of the whisker/matrix interface of the T6 treated composite. The growth direction of the whisker is parallel to the surface of photograph.

$\mathrm{K}_{2} \mathrm{O} \cdot 6 \mathrm{TiO}_{2}$ の (201) 面, アルミニウム中の格子は面心 立方構造の（200）面を示している。この反応生成物は, 前述したマグネシウムのウイスカー/マトリックス界面 


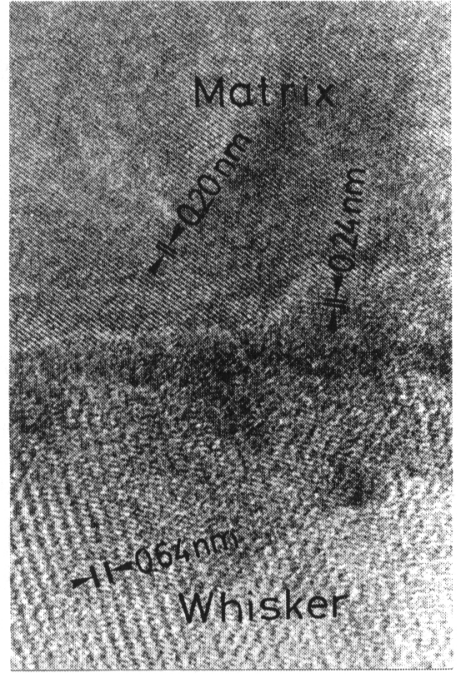

Photo. 7. HREM photograph of the whisker/matrix interface of the as-cast composite. The growth direction of the whisker is vertical to the surface of the photograph.

への偏析を考慮すると, マグネシウムが関与したものと 考えられるが，この格子からだけでは同定はできない. $0.24 \mathrm{~nm}$ の面間隔を有するものとしては, $\mathrm{Mg}_{2} \mathrm{Si}, \mathrm{MgO}$ や $\mathrm{MgAl}_{2} \mathrm{O}_{4}$, あるいは $\mathrm{K}, \mathrm{Ti}$ を含んだ多くの複合酸化 物が考えられる。一方，この反応生成物の他に，格子縞 のほとんど観察されない領域がウィスカー表面に数 $\mathrm{nm}$ の幅で存在する．この層は，ウィスカーと不規則な界面 を持ちコントラストは濃く, 前述のウィスカー表面の濃 いコントラストの部分に相当すると考えられる.しかし， 層の幅が非常に狭いため分析は不可能であり，この反応 層が何らかの結晶構造を持つものであるか, またはアモ ルファスであるかを決定するためにはより詳細な検討を 要する.

以上のように，この複合系においてはミクロスケール でもウイスカーからのカリウム, チタンの溶出は認めら れない. ただし，合金元素のマグネシウムがウィスカー 表面に偏析し, 反応生成物を形成するが，その反応層の 厚さは数 $\mathrm{nm}$ と非常に薄いものである. 以上, 得られた 界面組織より総合的に判断して,このウィスカーは 6061 合金中で安定に存在すると言える.

\section{$3 \cdot 3$ 押出し T 6 材の物理的性質}

チ夕ン酸カリウムウィスカー強化材の物理的性質を 6061 合金, 及びその $15 \mathrm{vol} \%$ アルミナ短緎維強化材と 比較して Fig. 2 に示した.アルミナ短纎維強化材のデー

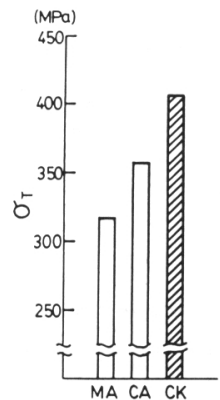

(a)

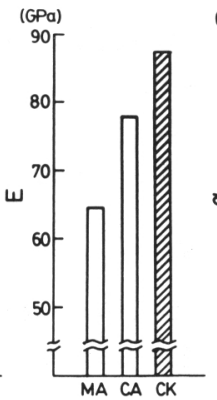

(b)

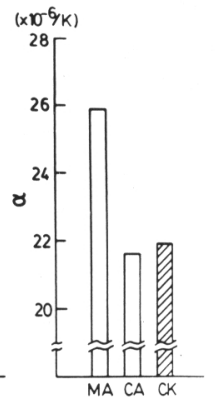

(c)
Fig. 2. (a) tensile strengths, $\sigma_{T}$, (b) Young's moduli, $E$, and (c) thermal expansion coefficients, $\alpha$, of 6061 alloys without any reinforcement (MA), with 15 vol\% alumina short fiber $(\mathrm{CA})^{4)}$ and with 20 vol\% potassium titanate whisker (CK). All were extruded at $773 \mathrm{~K}$ and $\mathrm{T} 6$ treated.

夕は，筆者らの以前の報告によるものである4)、いずれ の材料も同条件で熱間押出しを施したものである.チ夕 ン酸カリウムウィスカー強化材は, マトリックス合金よ り引張強さ及びヤング率のいずれに関しても $30 \%$ 高 く, 熱膨張率では $25 \%$ 低い值を持つ.アルミナ短緎維 強化材と比較すると, 体積率の違いを考えると熱膨張率 に関してはやや大きくなるが，引張強さに関しては 15\%，ヤング率に関しては 10\% 高い值であり，十分な 複合強化が達成されていると言える. また, 前述のよう にアルミナ短繊維に比べると押出し後のアスペクト比が 大きいことは，ひとつの利点になると考えられる．押出 し材の $\mathrm{T} 6$ 処理を施していない試料の平均引張強さは $298 \mathrm{MPa}$ であり，これが T6 処理で Fig. 2 のように $410 \mathrm{MPa}$ に上昇した.

このように, 本研究で用いたチタン酸カリウムウィス カーは, 6061 合金との複合化において良好な強度を達 成し, しかも $\mathrm{T} 6$ 処理で強度劣化を生じないことが明確 になった.また,これらの事実からウィスカーとマトリッ クスの間に反応が生じたとしても極めてわずかであり， 複合材料全体の強度に大きく影響するものではないこと が裏付けされる.

このウィスカーが FRM 用強化繊維として実用化され るためには，このウィスカーを用いた FRM の耐熱性, 疲労特性等の多くのデータの蓄積を必要とする.さらに, 本実験で用いた合金はあくまでもアルミニウム合金のモ デル材料として選んだものであり，例えば AC8A 等の 実用合金になる場合にはその合金元素との反応を考慮せ ねばならない.しかし，アルミニウム合金の中で最も活 
性な合金元素がマグネシウムであることを考えれば，他 の実用合金も本実験結果の延長線上にあり，それほど反 応が激しくなるとは考え難い。したがって，このチタン 酸カリウムウィスカーは，アルミニウム合金の強化䄉維 として用いることができると結論される.

\section{4. 結}

論

本研究では，新しく改良されたチタン酸カリウムウィ スカーを用い, 高圧鋳造法による 6061 合金との複合化 を行い，その 6061 合金との適合性に関し調べた．その 結果, 次の事柄が明らかになった。

( 1 ) 本実験条件の範囲（高圧鋳造時の $1073 \mathrm{~K}$ の溶湯 との接触，または $\mathrm{T} 6$ 処理）では,チタン酸カリウムウィ スカーより合金側へのカリウムやチタンの溶出は生じ ず， ウィスカーはマトリックス中に安定に存在する.

( 2 )合金元素のマグネシウムが多少ウィスカーの周り
に偏析するが，このため生じる反応層の厚さは $10 \mathrm{~nm}$ 以下でありたいへん薄い。

( 3 )本ウィスカーにより 6061 合金は十分に強化され た.

このように，本実験で用いたチタン酸カリウムウィス カーは，6061 合金との適合性はたいへん良好であると 言える.

\section{文献}

1）福永秀治，武市通文，太田進啓: 日本複合材料学会誌， 8 (1982), p. 66

2 ) T. Imai, Y. Nisida, $M$. Yamada, $I$. ShiRayanagi and $H$. MatsubaRA: J. Mater. Sci. Letters, 6 (1987), p. 1257

3 ）西田義則, 今井恒道, 山田 守, 松原宏美, 白柳 格: 軽金属, 38 (1988), p. 515

4 ) $K$. Suganuma, $T$. Fujta, $K$. Ninara, $T$. Окamoto and $N$. SuzuKI: Presented at the Inter. Meeting on Advanced Materials, Tokyo (1988), 印刷中

5 ）小菅張弓: 軽金属, 38 (1988), p. 292 